\title{
Pengembangan Aplikasi Timbangan Berat Produk
}

\author{
${ }^{1}$ Fery Setiawan, ${ }^{2}$ Otto Fajarianto, ${ }^{3}$ Ali Firdaus \\ ${ }^{1}$ STMIK Triguna Utama, ${ }^{2}$ STMIK Bina Sarana Global, ${ }^{3}$ Universitas Muhammadiyah Tangerang \\ Email: ${ }^{1}$ fery_setia@yahoo.com, ${ }^{2}$ ofajarianto@gmail.com, ${ }^{3}$ zhafiffirdaus@gmail.com
}

\begin{abstract}
In the industrial world the utilization of the scales is important for measuring production needs. The accuracy of the scales data greatly affects how much raw material is required in producing a product. Recording the results of the scales that are still manual using stationery is often the operator scales incorrectly incorporate gross and net. For the desired results of the scales then required a system that can any material that will be weighed in real time. Recording the scales data in real time can reduce operator recording errors in entering gross and net values. The Prototype method used for. In the process of working the system. The process undertaken from the data through checking to the field to see the results of recording the scales and conduct interviews or provide some questions to the operator of the constraints that often occur. From the data is processed as the basic needs of users of the system. The last stage of application creation and implementation. The results of this study are a system that can help the operator not to occur in recording the results of gross and net scales. The data collection of the scales will be recorded automatically and stored into the database. The results of the scales can be accessed by the user and made in the form of reports.
\end{abstract}

\section{Keyword : pair of scales; product, prototype}

Abstrak-Dalam dunia industri pemanfaatan timbangan sangatlah penting untuk mengukur suatu kebutuhan produksi. Keakuratan data timbangan sangat mempengaruhi berapa banyak bahan baku yang dibutuhkan dalam menghasilkan suatu produk. Pencatatan hasil timbangan yang masih manual menggunakan alat tulis sering mengakibatkan operator timbangan salah memasukkan nilai bruto dan netto. Untuk mendapatkan hasil yang akurat dari timbangan tersebut maka dibutuhkan suatu sistem yang dapat merekam setiap bahan yang akan di timbang secara real time. Perekaman data timbangan secara real time dapat mengurangi kesalahan pencatatan operator dalam memasukan nilai bruto dan neto. Metode Prototype digunakan untuk membuat tahapan dalam pengerjaan sistem tersebut. Proses yang dilakukan dimulai dari pengumpulan data melalui pengecekan ke lapangan melihat hasil pencatatan timbangan dan melakukan interview atau memberikan beberapa pertanyaan kepada bagian operator terhadap kendala yang sering terjadi. Dari data tersebut diolah sebagai dasar kebutuhan user terhadap sistem. Tahap terakhir pembuatan aplikasi dan implementasi. Hasil dari penelitian ini adalah sistem yang dapat membantu operator agar tidak terjadi kesalahan dalam pencatatan hasil timbangan bruto dan neto. Pengambilan data timbangan tersebut akan terekam secara otomatis dan disimpan ke dalam database. Riwayat hasil dari timbangan tersebut dapat diakses oleh user dan dibuat dalam bentuk laporan.

Kata Kunci: timbangan, produk, prototype 


\section{Pendahuluan}

PT Tembaga Mulia Semanan, Tbk merupakan perusahaan yang bergerak dibidang pembuatan kawat tembaga dan aluminium. Salah satu unit bisnisnya adalah Drawing yang khusus menghasilkan produk kawat tembaga dengan diameter dibawah $2 \mathrm{~mm}$.

Penimbangan adalah proses akhir produksi sebelum dikirimkan ke pelanggan. Sistem manual penimbangan yang berjalan adalah sebagi berikut:

1. Operator menaruh produk ke timbangan.

2. Nilai bruto akan tampil di LED mesin GST-9600.

3. Operator menulis secara manual ke kertas timbangan 4 rangkap.

4. Operator menempelkan kertas timbangan ke produk dan memindahkan produk ke gudang.

Dari proses yang berjalan sering timbul masalah dalam penulisan nilai bruto. Belum lagi jika kertas yang ditulis hilang, akan memakan waktu untuk melacak berat produk tersebut.

Aplikasi timbangan adalah cara untuk menghilangkan kesalahan memasukkan berat bruto dan untuk memudahkan pelacakan produk. Diharapkan proses timbangan bisa lebih efektif dan efesien dengan menggunakan aplikasi ini.

\section{KAJIAN LITERATUR}

Penelitian ini membahas mengenai perancangan dan realisasi sistem display yang digunakan untuk mengukur hasil keluaran dari Timbangan Gantung Digital dengan Wireless tipe KGS 5.10.15.20 produk dari CV. General "PLC"Service . Timbangan jarak jauh sangat diperlukan untuk mempermudah proses penimbangan. Terutama untuk penimbangan objek yang besar sehingga berbahaya jika melihat hasil timbangan dengan jarak dekat. Pada sistem yang ada pada timbangan tersebut, hasil pengukuran dikirimkan menggunakan frekuensi UHF ke tempat lain. Sensor berat yang digunakan yaitu sensor Loadcell dengan keluaran tegangan DC. Pada bagian pemancar, data hasil pengukuran dari sensor diproses oleh: Analog to Digital Converter, mikrokontroler, kemudian dipancarkan melalui saluran transmisi udara. Pada bagian penerima terdiri atas: telecontrol 2005, Konverter level TTL ke RS232. Untuk menampilkan hasil pengukuran, menggunakan Personal Computer (PC) dengan program Visual Basic 6.0 sistem timbangan ini sangat menguntungkan, selain dapat menimbang beban dengan jarak jauh, Penggunaan sistem serial memungkinkan untuk menggunakan kabel serial sampai jarak 20 meter. Untuk pengembangan tampilan visual basic dapat ditambahkan sistem database, agar data hasil penimbangan dapat tersimpan di PC. [1]

Penggunaan timbangan mulai dari timbangan jenis konvensional, digitalsampai pada jenis timbangan dinamis. Timbangan digital merupakan salah satu jenistimbangan yang memiliki nilai keakuarasian lebih tinggi dari pada jenis timbangan konvensional(mekanik). Dalam rancang bangun timbangan digital dengan pemilihan jenis buah ini, diperlukan beberapa perangkat diantaranya ialah perangkat keras dan perangkat lunak. Perancangan dan pembuatan sistem perangkat keras meliputi 5-unit rangkaian elektronik, yaitu meliputi perancangan rangkaian sensor berat (Load Cell), dengan berat maksimal $5 \mathrm{~kg}$ rangkaian minimum sistem mikrokontroler Atmega16, danrangkaian LCD, dan keypad. Sedangkan perancangan untuk perangkat lunak meliputipemrograman bahasa $\mathrm{C}$ (codevivsion AVR). Dalam rancang bangun timbangan digital dengan pemilihan jenis buah, didapatkan hasil pengujian yang menunjukkan karakteristik sensor ketika diberi beban mulai dari $0,5 \mathrm{~kg}-5 \mathrm{~kg}$ bersifat linier. 
Maksud dari sifat liner adalah perubahan keluaran sensor yang konstan terhadap beban yang diberikan. Pada hasil pengujian didapatkan error sebesar $1,2 \%$, dan memilki ketelitian penimbangan100/gram. Dari rancang bangun timbangan digital dengan pemilihan jenisbuah didapatkan bahwa harga satuan buah dapat diubah mulai dari Rp.0000 - Rp. 9999. Harga akumulasi merupakan perkalian dari berat buah terhadap harga satuan. Sedangkan untuk kerja dari sensor berat dapat bekerja sesuai dengan karakteristik kerjadari 0 kg-5 kg. Dari hasil pengujian dan analisis didapatkan bahwa timbangan digitaldengan pemilihan jenis buah dapat bekerja dengan baik, ketika diberi masukkan tegangan5 VDC, dan Keluaran sinyal listrik dari sensor akan mengalami kenaikan apabilamendapatkan beban dan akan mengalami penurunan apabila beban dikurangi. [2]

Agar mudah, cepat, tepat, akurat dan efisien. Penerapan teknologi dimanfaatkan dalam semua bidang, salah satu wujud penerapan sistem teknologi dalam bidang pengukuran adalah timbangan digital. Alat ini merupakan peraga sebagai alat pengukur suatu berat benda yang di harapkan dapat membantu tidak hanya para pedagangnya tetapi juga para pembeli dengan cara selain menampilkan hasil pengukuran berat melalui LCD,tetapi juga dikeluarkan melalui suara. Alat ini dirancang menggunakan sensor Flexiforce yang di desain untuk mengukur berat obyek. Sensor Flexiforce ini mengubah besaran fisik (berat) menjadi sebuah perubahan resistansi yang berbeda-beda untuk setiap pengukuran berat. Rangkaian yang digunakan untuk merubah keluaran sensor dari perubahan resistansi menjadi perbahan tegangan adalah menggunakan rangkaian jembatan Wheatstone dan rangkaian pengkondisi sinyal berupa rangkaian instrumentasi. Mikrokontroller yang digunakan untuk pengendali system adalah ATmega 8535, ISD (Information
Storage Device)2560 digunakan sebagai penyimpan database suara. Sebagai verifikasi data teks digunakan LCD M1632. Pengujian dilakukan dengan menggunakan berat benda yang berbedabeda. Hasil pengujian menunjukkan bahwa alat dapat mendeteksi berat benda yang ingin diukur beratnya serta mengeluarkan hasilnya dalam bentuk suara serta tampilan teks di LCD sesuai dengan berat benda tersebut. Nilai kesalahan rata-rata pengujian alat secara keseluruhan adalah 4,32\%. [3]

Penggunaan alat bantu tersebut tidak hanya dapat dimanfaatkan pada bidang industri saja tetapi pada bidang visual alat bantu juga dapat berguna. Alat bantu sering digunakan seseorang dalam memberikan penjelasan pada orang lain melalui media. Hal ini juga dilakukan pada guru matematika yang menggunakan alat bantu dengan flash player untuk memberikan penjelasan kepada muridnya agar lebih mudah. [4]

\section{Metodologi}

Dalam melakukan penelitian ini digunakan metode Prototype. Prorotype adalah suatu proses yang memungkinkan pengembang membuat sebuah model perangkat lunak. Adapun tahapannya sebagai berikut:

1. Pengumpulan Kebutuhan. Penulis dan operator timbangan bertemu terlebih dahulu dan kemudian menentukan tujuan umum, kebutuhan yang diketahui dan gambaran-gambaran yang dibutuhkan.

2. Perancangan. Selanjutnya, dilakukan perancangan aplikasi timbangan di sisi antarmuka dan basisdata.

3. Mengkodekan sistem.

4. Pengujian sistem

5. Penilaian sistem. Operator timbangan melakukan penilaian apakah sistem sudah sesuai yang diharapkan. 
6. Penerapan sistem

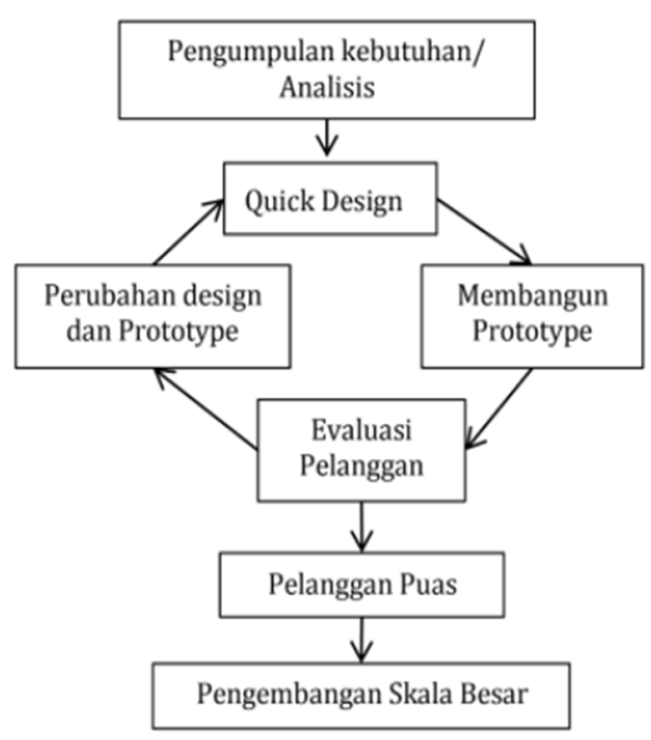

Gambar 1. Metode Prototype

Diagram alir merupakan algoritma yang terstruktur yang menggambarkan urutan logika dari suatu prosedur pemecahan masalah .[5]

\section{PHP}

PHP berawal dari cara sederhana Rasmus Lerdof dalam melacak pengunjung situsnya. Setelah pengembangannya dilepaskan ke umum, PHP banyak kebanjiran saran sehingga muncul PHP 1.0. Kemampun yang ditanamkan pada PHP 1.0 adalah menyaring masukan dan mengganti perintah sederhana untuk HTML. Seiring naiknya popularitas PHP, Rasmus belajar YACC dan GNU Bison lalu membuat PHP 2 (PHP/FI).

Di versi PHP/FI ada banyak fitur yang ditawarkan, yaitu: pengembang diizinkan menanam struktur kode didalam etiket HTML, PHP dapat mengurai data diajukan oleh formulir HTML, komunikasi dengan basisdata dan membuat perhitungan rumit secara langsung. PHP mulai digunakan untuk situs komersial pada tahun 1996.

Fitur-fitur baru mulai dikembangkan di versi PHP selanjutnya. Salah satunya adalah DIO (Direct Input/Output) yang digunakan untuk komunikasi dengan RS 232 yang ada di PHP 5.0. Versi terbaru dari PHP adalah 7.2. [6]

\section{MySQL}

MySQL adalah sistem pengelolaan basisdata sumber terbuka yang paling populer. Dibuat oleh perusahaan MySQL AB, MySQL pertama kali diterbitkan untuk internal pada tahun 1995 dan baru tahun 1996 untuk umum. Versi terakhir adalah MySQL 8. [7]

Beberapa faktor yang menyebabkan MySQL terkenal, yaitu:

1. Ukuran dan Kecepatan.

2. Mudah pemasangan.

3. Perhatian pada standar.

4. Mau mendengarkan ke komunitas.

5. Antarmuka mudah terhadap perangkat lunak lain.

\section{Port Serial RS 232}

RS232 adalah sebuah standar komunikasi serial yang membuat data dapat dipindahkan dalam bentuk serial diantara dua perangkat [8]. Data dikirim dan diterima dalam aliran bit serial dari satu titik ke titik lainnya. Ada empat parameter yang menentukan sebuah tautan RS232 diantara dua peragnkat, yaitu:

1. Baud rate: menentukan seberapa banyak informasi dipindahkan terhadap waktu (bits per second). Sebuah baud rate dapat dipilih diantara 110 sampai 76800 .

2. Data width: dapat berupa 8 atau 7-bit tergantung terhadap kebiasaan data sedang dipindahkan.

3. Parity: parity digunakan untuk memeriksa kebenaran dari data yang dipindahkan atau diterima. Nilai parity dapat berupa even, odd, atau no parity. 
4. Stop bit: Stop bit digunakan sebagai pemutus bit dan dimungkinkan menentukan antara satu atau dua stop bit.

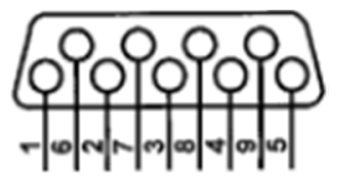

Gambar 2. 9 saluran RS 232

Keterangan tentang saluran di RS 232 adalah sebagai berikut:

1. Carrier detect (CD): Sinyal ini menunjukkan bahwa sinyal pembawa telah dikenali oleh modem terhubung ke saluran.

2. Receive data (RD): Menerima data.

3. Transmit data (TD): Mengirimkan data.

4. Data terminal ready (DTR): Sinyal ditegaskan untuk menunjukkan bahwa perangkat siap.

5. Signal ground (SG): sinyal ground.

6. Data set ready (DSR): Sinyal ini menunjukkan, berdasarkan perangkat pada akhiran lain, yang sudah siap.

7. Request to send (RTS): Sinyal ini ditegaskan ketika perangkat meminta data untuk dikirim.

8. Clear to send (CTS): Sinyal ini ditegaskan ketika perangkat siap menerima data.

9. Ring indicator RI): Menunjukkan ke perangkat bahwa saluran berbunyi.

\section{GST-9600}

GST-9600 adalah indikator berat digital yang dirancang untuk memastikan kualitas dan keakuratan timbangan [9]. Port keluarannya adalah RS-232C dan Passive 20mA yang memungkinkan beradaptasi dengan perangkat lain untuk beragam tugas timbagan sepertikendali jarak jauh, kendali timbangan otomatis dan timbangan truk.

Nilai-nilai awalan untuk parameter RS232 GST-9600 adalah sebagai berikut:

1. Baud rate: 2400 bps
2. Data bits: 7

3. Parity bit: Even

4. Stopbit: 1

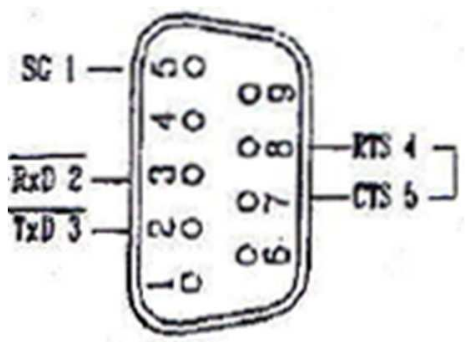

Gambar 3. Pengaturan Pin GST 9-600

\section{HASIl DAN PEMBAHASAN}

Pada penelitian ini dirancang suatu aplikasi timbangan dimana operator timbangan tidak perlu memasukkan nilai bruto dan netto. Diharapkan kehadiran aplikasi ini menghilangkan kesalahan memasukkan nilai bruto dan netto.

Dalam membangun aplikasi ini keseluruhan komponen yang dilibatkan adalah sebagai berikut:

1. Perangkat lunak: aplikasi timbangan, peramban Google Chrome dan basisdata MySQL.

2. Perangkat keras: komputer dimana perangkat lunak terpasang dan Digital Weighing Indicator GST-9600.

3. Operator timbangan yang menjalankan aplikasi.

4. Prosedur, yaitu langkah-langkah tentang penggunaan sistem.

Dari keseluruhan komponen aplikasi tersebut, maka didapatkan masukan dan keluaran sebagai berikut:

Masukan: Data pelanggan, No. Produksi, Diameter/Size, Pitch, Elongation, Gross, Tare, Operator dan Operator QA.

Keluaran: Hasil masukan data akan disimpan ke basisdata untuk kemudian dicetak.

\section{Gambaran Sistem}

Agar komputer PHP dapat membaca sinyal yang dikirimkan dari GST-9600, maka harus disesuaikan pengaturan. 
Gambaran sistem secara umum dapat dilihat pada Gambar 4. Pertama-tama operator harus memasukkan data sesuai dengan isi formulir yang telah disiapkan. Setelah data tersebut terisi maka nilai Netto akan dikurangi secara otomatis. Tahapan berikutnya operator harus mengklik tombol simpan agar data yang dimasukan dapat tersimpan ke basisdata dan langsung menampilkan pratinjau cetakan. Jika ingin mencetak hasil perhitungan timbangan tersebut maka dapat memilih tombol Print atau tombol Cancel untuk membatalkan pencetakan.

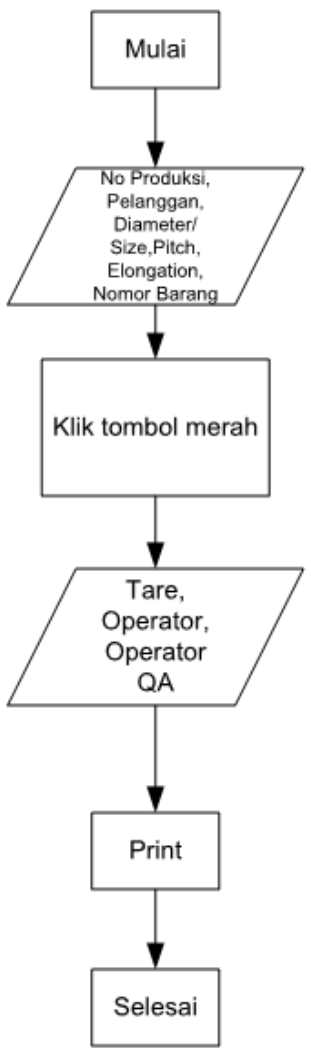

Gambar 4. Diagram Alir Aplikasi Timbangan

Proses ini dapat dilakukan dengan mudah oleh operator timbangan tanpa harus mencatat secara manual setiap proses transaksi. Semua data masukan yang sudah diinput tidak akan hilang karena akan tersimpan pada basisdata dan history datanya pun akan terjaga dengan baik.

Pada Gambar 5 terlihat form untuk penginputan data yang dibutuhkan untuk perhitungan hasil penimbangan. Data tersebut akan di olah secara otomatis. Sedangkan pada gambar 6 dapat terlihat hasil penimbangan dari perhitungan data yang dimasukan dalam form timbangan. Aplikasi dapat melakukan pembacaan nilai Bruto dengan menekan gambar lingkaran bewarna merah. Setelah semua data dimasukkan, klik tombol PRINT untuk menyimpan ke basisdata.

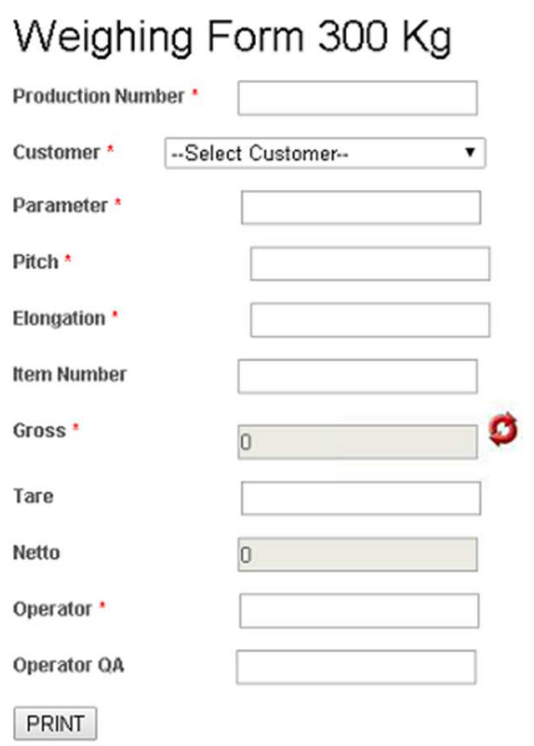

Gambar 5. Form Penginputan Data

\section{SCALE IT CDW Weighing: ScalelT I PCName: DRW-MTC-011-W}

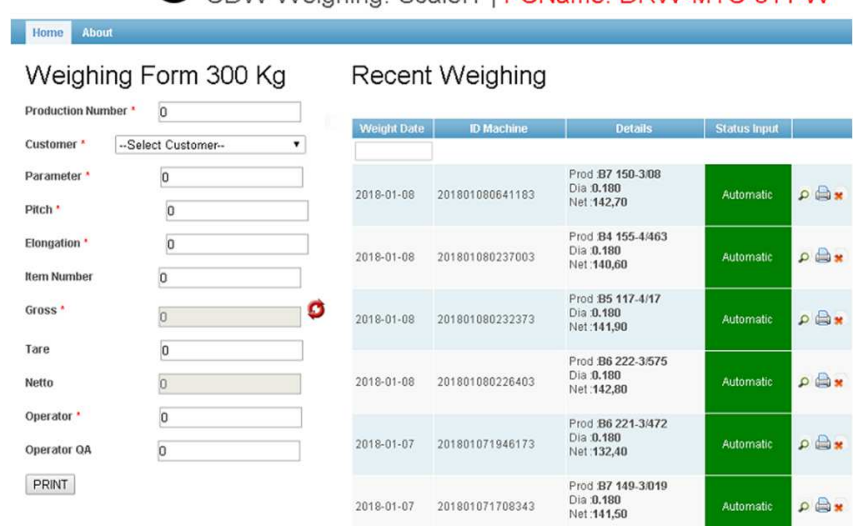

Gambar 6. Tampilan Hasil Penimbangan

\section{KESIMPULAN}

Kesimpulan yang dapat diambil dalam pengembangan aplikasi timbangan ini adalah sebagai berikut: 
1. Operator tidak perlu memasukkan nilai Bruto secara manual.

2. Riwayat hasil timbangan dapat dilacak dan dicetak ulang.

\section{Daftar Pustaka}

[1] Handajadi, Wiwik dan Ahmad Sholeh, Jurnal Teknologi, Volume 2 Nomor 1, Juni 2009, 96-107, "Pembacaan Output Timbangan Digital Jarak Jauh Dengan Menggunakan Pemprograman Visual Basic 6.0".

[2] Willy Bayu Erlangga dan Muladi, Jurnal Tekno, Volume 15, Nomor 1, 2011, "Rancang Bangun Timbangan Digital Dengan Pemilihan Jenis Buah"

[3] Ita Dwi Purnamasari, Jurnal Mahasiswa TEUB, Volume 1, Nomor 1, 2013, "Timbangan Digital Berbasis Sensor Flexiforce Dengan Output Suara"

[4] O Fajarianto, R Wirawa, "Aplikasi Alat Bantu Mengajar Matematika Menggunakan Adobe Flash CS6", Jurnal Sisfotek Global, 2013

[5] Yurindra, "Software Engineering", Yogyakarta, 2017, pp.47-50.

[6] Atkinson, Leon and Suraski, Zeev, "Core PHP Programming,", $3^{\text {rd }}$ Edition, United States of America, 2004, pp. 252-253.

[7] Tahaghoghi, Seyed \& Williams, Hugh E, "Learning MySQL", O’reilly Media, 2007. pp .4

[8] Sitorus, Lamhot, "Algoritma dan Pemrograman", Andi, Yogyakarta, 2015, pp.

14-15.

[9] 8051", Oxford, 2000, pp.148. 